\title{
Q\&A: Turning up the heat on sci-fi
}

The novel Hothouse is Brian Aldiss's extraordinary 1962 vision of rampant global warming, set on a future stationary Earth with one side permanently baked by the Sun. As the book is republished as a Penguin Modern Classic, the 83-year-old author shares his thoughts on science fiction and life with Nature.

\begin{abstract}
What sparked your vision of vigorous plants taking over Earth in Hothouse? My memories of the overwhelming exuberance of vegetation I saw in south and east Asia, where I was in action in the Second World War. The Sumatran jungle captured my imagination. I also remember a vast banyan tree in the Calcutta Botanical Gardens, said to be the biggest tree in the world. The power and energy of these plants was amazing.
\end{abstract}

Are you concerned about climate change? The situation is awful. To think we may lose the polar bears. And the idea that bees are in peril. If the bees go, there goes fertilization. We follow.

Climate change is very difficult to deal with because there's no carrot at the end of it. The temptation for present generations to hope future generations will sort it out with a technological fix is very strong.

When I wrote Hothouse, apart from the threat of nuclear war, the burning issue was population explosion. I'm surprised to see so little mention of this today. Perhaps it is because a sense of responsibility is lacking in the West: there may be fewer of us, but we are greedier and contribute much more per head to global heating than those in poorer regions.

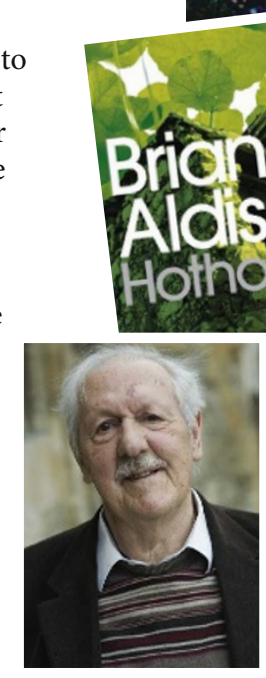

\section{How would you counter critics who argue that the book is scientific nonsense, for instance, attaching Earth to the Moon by giant cobwebs?}

It is science as fantasy. My premise for Earth and the Moon being stationary is that there is a 'trojan' position in which three heavenly bodies - in this case the Sun, Earth and the Moon - get locked into a position from which they cannot escape. I do not claim that Earth and the Moon have been fixed in position by spider webs between them; that's a widely held misunderstanding.

\section{Neil Gaiman's introduction says that the book is less optimistic than US science fiction of the same period. Do you agree? British science fiction is cautionary. You could argue we derived that from} Americans go to Mars and clobber
the martians. To some extent this thinking has changed. Science fiction has become darker, and I think I am one of the people who changed it.

H. G. Wells. His 1898 novel War of the Worlds is a homily against human arrogance. But the typical US mentality is that 'we can sort this out'. Garrett P. Serviss wrote a sequel to Wells's book called Edison's Conquest of Mars, in which

\section{What inspired you to write?}

As a child I had to live within my mother's awful delusion. I was 50 years old before I found out that my sister, who my mother said had died at the age of five, had in fact never lived - she was stillborn. That's the sort of thing that provokes one to invent many paradoxical worlds. I have always enjoyed inventing planets that contrast with Earth.

As a young man, coming back from the East after the end of the Second World War, I sat up on the deck of the troopship watching the bow waves and read Homer's Odyssey. It brought me back to worlds of

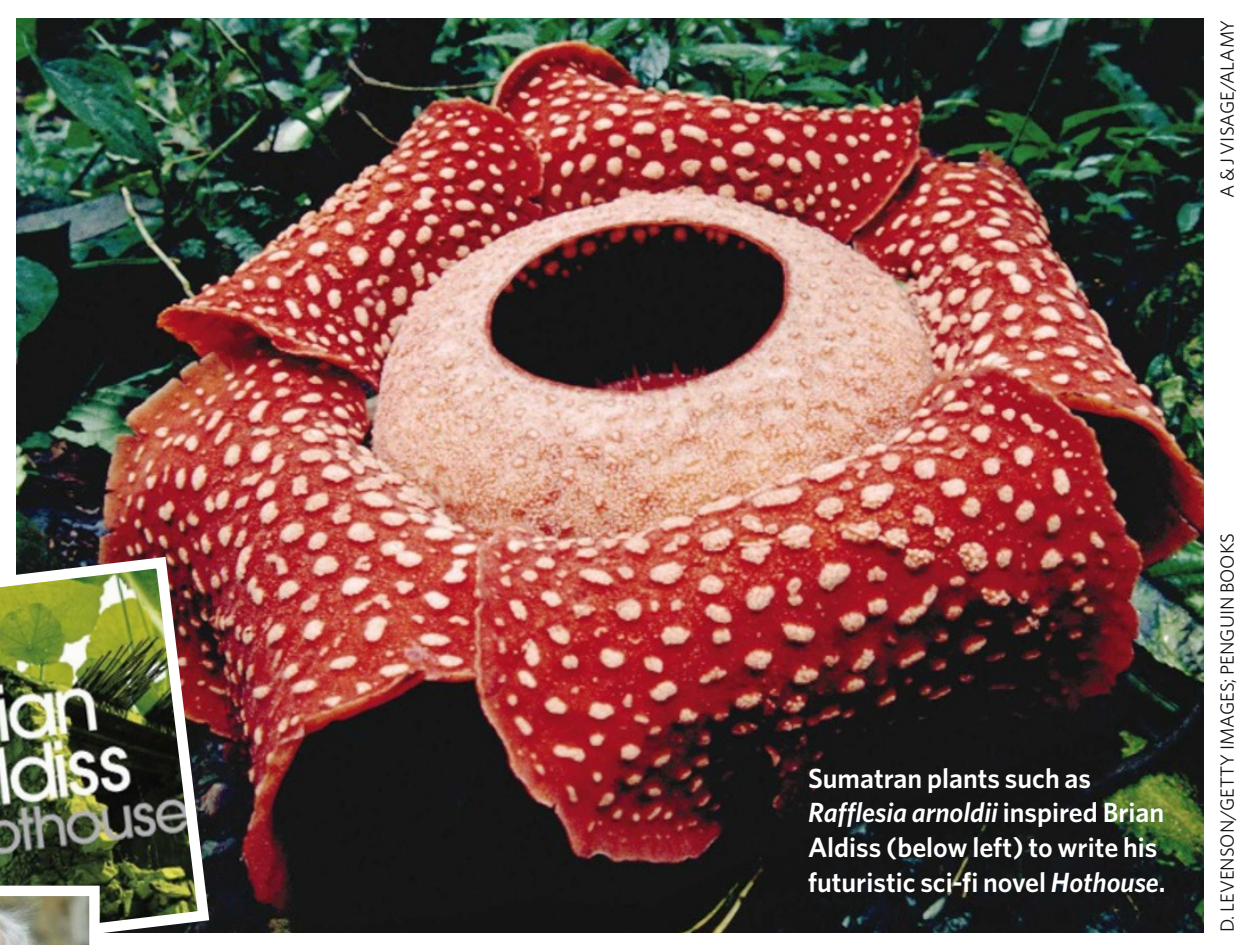

creativity. I particularly enjoy such stories of the Bronze Age just emerging into the Iron Age, as in my 2004 novel Jocasta.

\section{What influences your writing now?} My day-to-day life is very happy. Each morning I get up and am almost immediately excited by some inspiring idea. I'm reading six books at once, which is absurd! There was one more I wanted to read - Our Final Century by Martin Rees — but it's so pessimistic I couldn't face it.

I am attracted to what is most remote. In 2015, the NASA probe New Horizons will send back data from Pluto. We'll discover so much about what it is really like. I hope I live to see or hear about it all, even from a hospital bed. The probe will then go on to the Oort Cloud near the edge of the Solar System. Imagine! Interview by Caspar Henderson, a writer based in Oxford, UK. He is writing A Book of Barely Imagined Beings.

e-mail: caspar81@gmail.com

\section{Hothouse}

by Brian Aldiss

Penguin: 2008. 288 pp. Can\$19, £8.99 